\title{
REGULAR ARTICLE \\ VARIATION MINERAL COMPOSITIONS OF SOME BAMBARA GROUNDNUT (VIGNA SUBTERRANEA (L.) VERDC.) ACCESSIONS
}

\author{
M. I. ADEBOLA1 ${ }^{*}$, M. A. ADELANWA ${ }^{1}$, M. S. MOHAMMED², A. E. ESSON
}

${ }^{1}$ Department of Botany, Ahmadu Bello University, Zaria, Nigeria

${ }^{2}$ Department of Plant Science, Ahmadu Bello University, Zaria, Nigeria

\begin{abstract}
The study aimed to assess variation in mineral compositions of some accessions of Bambara groundnut (Vigna subterranea [L.] Verdc.) for domestic use and genetic enhancement. Twenty accessions of Bambara groundnut were planted in a Randomised Complete Block Design (RCBD) with three replications. The five minerals were analysed which include, calcium, magnesium, iron, zinc and manganese. These accessions showed significant $(\mathrm{P}<0.05)$ variations across the five mineral analysed. Accession no. 18 had the highest mean for iron (2.89 $\left.\mathrm{mg}_{100 \mathrm{~g}^{-1}}\right)$, Accession no. 12 had the highest mean value for zinc $\left(0.65 \mathrm{mg}_{100 \mathrm{o}^{-1}}\right)$ Accession no. 8 had the highest mean value for calcium $\left(217.36 \mathrm{mg}^{\circ} \mathrm{oog}^{-1}\right)$, magnesium $\left(14.29 \mathrm{mg} \mathrm{mog}^{-1}\right)$ and manganese $\left(0.82 \mathrm{mg}_{100 \mathrm{~g}^{-1}}\right)$. However, accession no. 12 had the lowest mean values in four of the minerals except zinc. This result showed that some of these accessions could be selected for genetic enhancement of minerals, some for domestic use and some for industrial use.
\end{abstract}

Keywords: Bambara groundnut, Genetic enhancement, Minerals, Accessions

\section{INTRODUCTION}

Bambara groundnut (Vigna subterranea (L.) Verdc.), also known as 'Okpa' (Igbo), 'gurjiya' or 'kwaruru' (Hausa) and 'Epa roro' (Yoruba) is cultivated mainly for its edible protein-rich seed. Its seeds are known as a complete food because they contain sufficient quantities of protein, carbohydrate and fat [1]. Thus, compared favourably nutritionally when compared with more commonly utilised and commercialised grain legumes. In many African countries, Bambara groundnut serves as a cheap source of protein and minerals of plant origin in areas where animal protein is very expensive [2] for enhanced human nutrition and animal feed.

The major challenge in the utilization of food resources is the lack of adequate information on the nutritional constituents [3]. For example, there are only limited knowledge about under-utilized legumes which are mainly used for human food and animal feeds in Nigeria [4].

The malnutrition is a serious problem in developing countries, due to lack of adequate meat consumption due to high price, making them unaffordable to people of low income [5]. It has been reported that more than $35 \%$ of the world population is manganese deficient [6]. Bambara groundnut may have great potential of sustaining the dietary needs of many people in both rural and urban communities and one of the many legumes that can provide the protein and minerals [2]. Therefore, estimation of its minerals value will provide valuable data for its use as a food and/or medication [7].

\section{MATERIALS AND METHODS}

The research was conducted at the Institute for Agricultural Research (IAR) Farm, Ahmadu Bello University, Zaria, (Lat $11^{\circ} 11^{\prime} \mathrm{N}$; Long $7^{\circ} 38^{\prime} \mathrm{E}$ and Altitude $660 \mathrm{~m}$ above sea level). Samaru lies in the northern guinea savanna agro ecological zone of Nigeria with a mean annual rainfall of about $1200 \mathrm{~mm}$ which is essentially between April to September and a mean daily temperature of $27^{\circ} \mathrm{C}$. The coldest months are November-January [8].

\section{Source of materials}

Healthy seeds of the Bambara Groundnut accessions were obtained from the local farmers within Giwa (Kaduna State), Kura and Gargai (Kano State) and Hadejia (Jigawa state). The accessions were grouped into twenty (20) groups based on their uniformity in ground colour, eye colour, pattern colour, eye pattern, body pattern and seed sizes.

\section{Sample preparation}

Dried seeds for each of the accessions were used for the determination of mineral constituents. Seeds devoid of any pest's damage were ground into fine powder using a small wooden pestle and mortar. The pestle and mortar were cleaned with sponge and water after pounding each accession. Each sample was then sieved through $20 \mathrm{~mm}$

\section{Received 11 October 2017; Accepted 21 December 2017}

\section{*Corresponding Author}

Adebola M. I.

Department of Botany, Ahmadu Bello University, Zaria

Email: adebolawonder@gmail.com

(This article is open access and licensed under the terms of the Creative Commons Attribution License (http://creativecommons.org/licenses/by/4.o/) which permits unrestricted, use, distribution and reproduction in any medium, or format for any purpose, even commercially provided the work is properly cited. Attribution - You must give appropriate credit, provide a link to the license, and indicate if changes were made. 
mesh iron to obtain fine textured flour. Using $1.25 \mathrm{~g}$ from each accession, Wet-ashing procedure described by Gorsuch (1959) was employed using nitric acid, perchloric acid and sulphuric acid in the ratio of $3: 2: 1$ with the Kjeldahl apparatus for the digestion.

The minerals determined were: Calcium (Ca), Magnessium $(\mathrm{Mg})$ and the micro-minerals estimated were Iron $(\mathrm{Fe})$, Zinc (Zn) and Manganese (Mn). These mineral concentrations were measured using a Varian Fast Sequential Atomic Absorption Spectrophotometer AA240FS Model. All analyses were carried out in duplicate and the analysis was carried out at the Multi-User Science Research Laboratory, Ahmadu Bello University, Zaria.

The data collected were subjected to analysis of variance (ANOVA) using Statistical Analysis System (SAS 9.1 version) to determine the significant difference for all the mineral contents. Where significant differences exist, Duncan's multiple range test (DMRT) was used to separate the means at $\mathrm{P}<0.05$.

\section{RESULTS}

The result obtained in table 1 indicated that there was significant difference at $\mathrm{P}<0.05$ in all the mineral compositions of the accessions studied. The highest composition of iron was found in accession no. 19 with $2.89 \mathrm{mg} \mathrm{Oog}^{-1}$ followed by accession no. 8 with 1.83 mg10og $^{-1}$ and accession 12 with 0.3 mg1oog was the lowest. Accession no. 8 had the highest calcium composition of $217.36 \mathrm{mg}^{-100 \mathrm{~g}^{-1}}$ while the lowest with 56.76 mg1oog $^{-1}$ was accession no. 12. Magnesium composition was found to be highest in accession no. 8 with $14.29 \mathrm{mg}_{100 \mathrm{og}^{-1}}$ while accession no. 12 with 7.12 $\mathrm{mg} / 100 \mathrm{~g}$ had the lowest composition. The highest zinc composition $0.65 \mathrm{mg} \mathrm{oog}^{-1}$ was found in accession no. 12 followed by accession no. 13 with $0.5 \mathrm{mg} \mathrm{oog}^{-1}$ whereas accession no. 7 had the lowest composition of 0.19 $\mathrm{mg}_{100{ }^{-1}}$. Accession no. 8 with $0.82 \operatorname{mg} \operatorname{loog}^{-1}$ had the highest manganese composition while accession no. 12 with mean of $0.29 \mathrm{mg} \mathrm{Oog}^{-1}$ had the lowest composition.

\section{DISCUSSION}

There were significant differences in all the minerals among the Bambara groundnut analysed in this study. These variations in the mineral contents of accessions were also reported by several authors like [2] in different accessions of Bambara groundnut in Botswana, Namibia, Swaziland, and in Congo Brazaville [10]. Similar result was reported in beans (Phaseolus vulgaris) by Inobeme et al. [11]. The range of the Calcium compositions in the accessions studied is greater than those recorded in Botsawana, Swaziland and Namibia on Bambara groundnut accessions by Amarteifo et al. [2], Abdulsalami and Sheriff [12] in Kano, Andzouana et al. [10] in Congo Brazaville and those in Cote d'Ivoire [13]. Also, comparing this variations of calcium with other legumes, this study reported a higher composition than accessions of beans [11], groundnut [14], and Pisum sativum [15]. However, Mucuna pruriens (velvet beans) was reported to have a higher composition of calcium [16]. This indicates that the accessions under study have a great potential as a source of calcium to both humans and animal diets. Calcium functions as a constituent of bones and teeth, in blood and milk clotting, in the functioning of nerves and muscle contraction [4]. The magnesium contents of the accessions do not conform with the reports in different Bambara groundnut accessions by [2] [17] [18] [13], as well as in Brebra seed [19] and in Pisum sativum [15] which were found to be low. However, higher amount than what was observed in this study were reported in Bambara groundnut by Andzouana et al. [10], Phaseolus vulgaris [20] and groundnut [14]. Magnesium plays the role of proper functioning of muscles and central nervous system, enzyme activity, energy production, mineral balances.

Table 1: Mineral compositions (mg1oog $\left.{ }^{-1}\right)$ of 20 accessions of bambara groundnut

\begin{tabular}{|c|c|c|c|c|c|}
\hline \multirow[t]{2}{*}{$\mathbf{A C C}$} & \multicolumn{5}{|c|}{ Mineral elements $\left(\mathrm{mg1oog}^{-1}\right)$} \\
\hline & $\mathbf{F e}$ & $\mathbf{C a}$ & Mg & $\mathbf{Z n}$ & Mn \\
\hline 1 & $1.57^{\mathrm{d}}$ & $180.99^{\mathrm{d}}$ & $11.00^{g}$ & $0.41^{\mathrm{d}}$ & $0.74^{\mathrm{b}}$ \\
\hline 2 & $0.87^{\mathrm{k}}$ & $87.30^{s}$ & $11.08^{\mathrm{f}}$ & $0.30^{\mathrm{i}}$ & $0.45^{1}$ \\
\hline 3 & $0.66^{\mathrm{m}}$ & $128.78^{1}$ & $10.23^{1}$ & $0.27^{1}$ & $0.5^{8}$ \\
\hline 4 & $1.01^{\mathrm{h}}$ & $98.93^{p}$ & $11.26^{\mathrm{e}}$ & $0.41^{\mathrm{d}}$ & $0.54^{\mathrm{i}}$ \\
\hline 5 & $0.38^{q}$ & $101.46^{\circ}$ & $10.42^{\mathrm{i}}$ & $0.20^{\mathrm{n}}$ & $0.41^{\mathrm{m}}$ \\
\hline 6 & $0.85^{1}$ & $147.88^{\mathrm{h}}$ & $12.29^{b}$ & $0.30^{\mathrm{i}}$ & $0.61^{\mathrm{f}}$ \\
\hline 7 & $0.5^{p}$ & $15^{2.48^{\mathrm{g}}}$ & $9.72^{\mathrm{p}}$ & $0.19^{\circ}$ & $0.46^{1}$ \\
\hline 8 & $1.83^{b}$ & $217 \cdot 36^{\mathrm{a}}$ & $14.29^{\mathrm{a}}$ & $0.49^{c}$ & $0.82^{\mathrm{a}}$ \\
\hline 9 & $1.02^{\mathrm{g}}$ & $92.09^{r}$ & $9.41^{\mathrm{q}}$ & $0.35^{\mathrm{h}}$ & $0.54^{\mathrm{i}}$ \\
\hline 10 & $0.64^{n}$ & $117.04^{\mathrm{m}}$ & $11.94^{\mathrm{c}}$ & $0.26^{\mathrm{m}}$ & $0.5^{2^{j}}$ \\
\hline 11 & $0.62^{\circ}$ & $92.48^{\mathrm{q}}$ & $9.78^{\circ}$ & $0.39^{\mathrm{e}}$ & $0.61^{f}$ \\
\hline 12 & $0.30^{r}$ & $56.76^{t}$ & $7.12^{\mathrm{s}}$ & $0.65^{\mathrm{a}}$ & $0.29^{n}$ \\
\hline 13 & $0.85^{1}$ & $130.04^{\mathrm{k}}$ & $10.87^{\mathrm{h}}$ & $0.50^{b}$ & $0.5^{h}$ \\
\hline 14 & $1.63^{\mathrm{c}}$ & $106.74^{\mathrm{n}}$ & $10.05^{\mathrm{m}}$ & $0.28^{\mathrm{k}}$ & $0.49^{k}$ \\
\hline 15 & $0.98^{\mathrm{i}}$ & $188.49^{\mathrm{b}}$ & $10.33^{\mathrm{k}}$ & $0.37^{f}$ & $0.68^{d}$ \\
\hline 16 & $1.29^{\mathrm{e}}$ & $154.61^{f}$ & $11.89^{d}$ & $0.35^{\mathrm{h}}$ & $0.7 \mathrm{Oc}$ \\
\hline 17 & $0.63^{n}$ & $182.13^{\mathrm{c}}$ & $10.36^{j}$ & $0.35^{\mathrm{h}}$ & $0.68^{\mathrm{d}}$ \\
\hline 18 & $1.03^{f}$ & $140.19^{j}$ & $8.74^{\mathrm{r}}$ & $0.29^{j}$ & $0.54^{\mathrm{i}}$ \\
\hline 19 & $2.89^{\mathrm{a}}$ & $179.72^{\mathrm{e}}$ & $10.00^{n}$ & $0.30^{\mathrm{i}}$ & $0.59^{g}$ \\
\hline 20 & $0.94^{j}$ & $147.82^{\mathrm{i}}$ & $10.99^{\mathrm{g}}$ & $0.36 \mathrm{~g}$ & $0.63^{\mathrm{e}}$ \\
\hline $\mathrm{SEM}_{ \pm}$ & 0.003 & 0.003 & 0.004 & 0.000 & 0.002 \\
\hline
\end{tabular}

Means with the same letter along a column are not significantly different $\mathrm{P} \geq 0.05$, using DMRT, KEY: $\mathrm{ACC}=\mathrm{Accessions}, \mathrm{Fe}=$ Iron, $\mathrm{Ca}=$ Calcium, $\mathrm{Mg}=$ Magnessium, $\mathrm{Mn}=$ Manganesse 
Reports had also indicated that DNA synthesis is slowed by insufficient magnesium [21]. In view of these, Acc. no. 8 was found to contain both high calcium and magnesium compositions, while acc. no. 12 had the lowest value of both minerals. This may be associated with the presence of phytic and oxalic acids which are anti-nutrients present in Bambara groundnut, most especially those with low concentrations as reported by Adegunwa et al. [22] and Yao et al. [13]. The nutritional value of legume seeds is often limited by the presence of anti-nutrients, such as tannins, phytic acid and enzyme inhibitors [23]. These antinutritional factors have the ability to bind some divalent metals such as calcium and magnesium thereby interfering with their metabolism [24] [4].

Micronutrients that were determined in this study include iron, zinc and manganesse. Accessions no. 19, 12 and 8 contained substantial amount of source of iron, zinc and manganese, respectively. While accessions no. 12, 7 and 12 had the lowest compositions, in that same order. The status of accession no. 12 which had the low compositions of iron, zinc and manganesse might be inferred due to the presence of phytic acid. However, high compositions of these three micro elements was reported in Mucuna pruriens by Vadivel and Janadharnan, [16] in Phaseolus vulgaris by Gouveia et al. [20] and in Bambara groundnut by Abdusalami and Sheriff[12]. Also, Amarteifo et al. [2], Ataise et al. [14], Inobeme et al. [11] and Yao et al. [13] reported higher compositions of iron and zinc than what was found in the present investigation. Furthermore, higher compositions of iron and zinc were reported in this study than those reported by Belewu et al. [18] and Andzouana et al. [10] in Bambara groundnut and in groundnut by Ayoola et al. [25]. Micro minerals even though needed in small quantity, are nevertheless needed for proper body functioning. Manganese is essential for metabolizing fat and protein, and is often related with milk production. Zinc is essential in growth of reproductive organs and oil glands. Iron is very essential for hemoglobin and healthy immune system [4] [26]. In view of the fact that micronutrient malnutrition is a serious problem in developing countries especially infants and pregnant women [27]. Infants need adequate micronutrients to maintain normal growth and development [28]. Observed variations reported in this study might be associated with the accessions' place of origin having an influence on the seeds compositions as reported by Gouveia et al. [20]. Therefore, the existence of this range of variability could exploited when selecting for appropriate sources of material for breeding purposes as well as other domestic and industrial use such as formulation of infant formula and animal feed. In accordance with the Recommended Dietary Allowance (RDA), Acc. no. 8 and few other accessions of Bambara groundnut can be selected for domestic use and genetic improvement programme.

\section{CONCLUSION}

There was significant variation in the five mineral compositions of the 20 accessions of Bambara groundnut,
Accession no. 19 had the highest iron content 2.8 $\mathrm{mg} / 100 g$. Calcium, magnesium and manganese were found be highest in accession no. $8(217.36 \mathrm{mg} / 100 \mathrm{~g}, 14.29$ $\mathrm{mg} / 100 \mathrm{~g}$ and $0.82 \mathrm{mg} / 100 g$ ) respectively. However, accession no. 12 had the lowest contents in calcium, magnesium and manganese and iron $(56.76 \mathrm{mg} / 100 \mathrm{~g}, 7.12$ $\mathrm{mg} / 100 g$, and $0.29 \mathrm{mg} / 100 \mathrm{~g}$ and $0.3 \mathrm{mg} / 100 \mathrm{~g}$ ) respectively but had the highest zinc content 0.65 $\mathrm{mg} / \mathrm{100g}$. This result suggest the importance of this accessions in a breeding program that aim at improving crops to meet specific dietary needs as well as instant utilization.

\section{REFERENCES}

1. National Research Council (NRC) 2006. Bambara Bean: Lost Crops of Africa. (Vol. II: Vegetables.). National Academy of Press, Washington DC. p. 52-73

2. Amarteifio, J. O., Tibe, O. and Njogu, R. M. 2006. The mineral composition of bambara groundnut (Vigna subterrenea (L.) Verdc.) grown in Southern Africa. African Journal of Biotechnology, 5: 2408-2411.

3. Aletor, V. A. and Omodara, O. A. (1994). Studies on some leguminous browse plants, with particular reference to their proximate, mineral and some endogenous anti-nutritional constituents. Animal Feed Science and Technology, 46:343-348.

4. Soetan, K. O., Olaiya, C. O. and Oyewole, O. E. 2010. The importance of mineral elements for humans, domestic animals and plants. African Journal of Food Science, 4:200-222.

5. Mamiro, P. S., Mbwaga, A. M., Mamiro, D. P., Mwanri, A. W. and Kinabo, J. L. 2011. Nutritional quality and utilization of local and improved cowpea varieties in some regions in Tanzania. African Journal of Food, Agriculture, Nutrition and Development, 11: 4490-4506.

6. Emsley, J. 2011. Nature's Building Blocks: An $A Z$ Guide to the Elements: Oxford University Press, Oxford

7. Fraizier W. C. and Westhoff, D. C. 2007. Food Microbiology $4^{\text {th }}$ edition, Tata McGraw-hill Publishing Company Limited, New Delhi. P. 234-240

8. Oluwasemire, K. O., and Alabi, S. O. 2004. Ecological impact of changing rainfall pattern, soil processes and environmental pollution in Nigerian Sudan and Northern Guinea Savanna Agro-Ecological Zones. Nigerian Journal Soil Research, 5:23-31.

9. Gorsuch, T. T. 1959. Radiochemical investigations on the recovery for analysis of trace elements in organic and biological materials. Analyst, 84:135-139.

10. Andzouana, M., Jean Bienvenu, M. and Attibayeba, F. 2014. Chemical and phytochemical compositions of Voandzeia substerranea Seeds. Pakistan Journal of Biological Sciences, 17:1083-1088.

11. Inobeme, A., Nlemadim, A. B., Obigwa, P. A., Ikechukwu, G. and Ajai, A. I. 2014. Determination of proximate and mineral compositions of white cowpea beans (Vigna unguiculata) collected from markets in Minna, Nigeria. International Journal of Scientific and Engineering Research, 5: 502-504.

12. Abdulsalami, M. S. and Sheriff, H. B. 2010. Effect of processing on the proximate composition and mineral content of bambara groundnut (Voandezeia subterranea). Bayero Journal of Pure and Applied Sciences, 3: 188-190. 
13. Yao, D. N., Kouassi, K. N., Erba, D., Scazzina, F., Pellegrini, N. and Casiraghi, M. C. 2015. Nutritive evaluation of the bambara groundnut Ci12 landrace (Vigna subterranea (L.) Verdc.) produced in Côte d'Ivoire. International Journal of Molecular sciences, 16: 21428-21441.

14. Ataise, V. N., Akinhanmi, T. F. and Ojiodu, C. C. 2009. Proximate analysis and physico-chemical properties of groundnut (Arachis hypogaea L.). Pakistan Journal of Nutrition, 8, 194-197.

15. Harmankaya, M., Özcan, M. M., Karadaş, S. and Ceyhan, E. 2010. Protein and Mineral Contents of Pea (Pisum Sativum L.) Genotypes grown in central Anatolian region of Turkey. South Western Journal of Horticulture, Biology and Environment, 1: 159-165.

16. Vadivel, V. and Janardhanan, K. (2000). Nutritional and anti-nutritional composition of velvet bean: an underutilized food legume in South India. International Journal of Food Science and Nutrition, 51:279-87.

17. Mkandiwire, C. H. 2007. Review of Bambara groundnut (Vigna subterranea (L.) Verdc.) production in Sub-Sahara Africa. Agricultural Journal, 2: 464-470.

18. Belewu, M. A., Fagbemi, T., Dosumu, O. O. and Adeniyi, M. O. 2008. Physico-chemical and antinutritional properties of some lesser known tree and leguminous seeds. International Journal of Agricultural Research, 3:237-242.

19. Andualem, B. and Gessesse, A. 2014. Proximate composition, mineral content and anti-nutritional factors of Bebra (Millettia ferruginea) seed flour as well as physicochemical characterization of its seed oil. Springerplus, 3:298-301.
20. Gouveia, C. S. S., Freitas, G., De Brito, J. H., Slaski, J. J. and De Carvalho, M. Â. A. P. 2014. Nutritional and mineral variability in 52 accessions of common bean varieties (Phaseolus vulgaris L.) from Madeira Island. Agricultural Sciences, 5:317-329.

21. Hartwig, A. 2001. Role of magnesium in genomic stability. Mutation Research, 475(1-2):113-121.

22. Adegunwa, M. O., Adebowale, A. A., Bakare, H. A. and Kalejaiye, K. K. 2014. Effects of treatments on the anti-nutritional factors and functional properties of bambara groundnut (Voandzeia subterranea) flour. Journal of Food Processing and Preservation, 38:1875-1881.

23. Murevanhema Y. Y. and Jideani, V. A. 2013. Potential of Bambara Groundnut (Vigna subterranea (L.) Verdc) Milk as a Probiotic Beverage-A Review. Food Science and Nutrition, 53:954-967.

24. Blood, D. C. and Radostits, O. M. 1989. Veterinary Medicine 7th edition, Balliere Tindall, London p.589630

25. Ayoola, P. B., Adeyeye, A. and Onawumi, O. O. 2012. Chemical evaluation of food value of groundnut (Arachis hypogaea) seeds. American Journal of Food and Nutrition, 2: 55-57.

26. Encyclopedia of Childrens Health 2017. http://www. healthofchildren. com

27. Batra, J. and Seth, P. K. 2002. Effect of iron deficiency on developing rat brain. Indian Journal of Clinical Biochemistry, 17: 108-114.

28. Rush, D. (2000). Nutrition and maternal mortality in the developing world. America Journal of Clinical Nutrition, 72:2125-2405. 